\title{
Unlocking the potential of value chains as climate change resilience strategies: can macadamia nuts (macadamia integrifolia) offer the gateway?
}

Bandason, W. ${ }^{1}$, Parwada, C. ${ }^{2}$, Musara, J.P. ${ }^{3}$, Nyamushamba, G.B. ${ }^{4}$ and Kaseke, T. ${ }^{5}$

Correspondence author: W. Bandason. Email: wbandason@gmail.com

\section{ABSTRACT}

The consequences of climate change threaten existing agriculture systems across Zimbabwe. The researchers examined the possibility and potential for developing a smallholder farmer driven macadamia nuts value chain. Using the case of Chipinge district, Manicaland province, Zimbabwe, the study evaluated the potential of macadamia nut value chain functions as a climate change resilience strategy in Zimbabwe. Challenges faced by actors and positive developments made in incorporating smallholders into the macadamia nuts production sector were explored. The role of local markets and producers in the international trade in macadamia nuts were also examined, using a modified stakeholder analysis framework. Triangulation, a mixed methodology, was used to adequately capture the various quantitative and qualitative dimensions along the macadamia nuts value chain pillars. A sample of 220 farming units including Estates, A1 and A2 farmers was proportionately selected for the study. Primary data were collected from Key Informants through interviews and personal communications. Secondary data were collected from Agritex officers, buyers, and the Macadamia Association of Zimbabwe farmers' records. The production-marketing interface for macadamia nuts is weakly coordinated in the study area as shown by the rudimentary production systems especially for the Al and A2 farmers. Results show that the major missing links are the limited application of extension driven production enhancers and the limited visibility of farmers in more rewarding export markets. Production scales have, however, been increasing with more farmers allocating

\footnotetext{
${ }^{1}$ Lecturer and PhD Student at the Women's University in Africa, Faculty of Agricultural Sciences, P.O. Box GD 32, Greendale, Harare, Zimbabwe. Email wbandason@gmail.com

${ }^{2}$ Professor, Regional Programme Coordinator: Department of Agricultural Management, Faculty of Agriculture. Matebeleland North Region. Zimbabwe Open University. P. O. Box MP 1119, Mount Pleasant; Email cparwada@gmail.com. Orcid 0000-00027960-4303

${ }^{3}$ Lecturer: Agricultural Economics and Agribusiness at Gwanda State University, Department of Crop Science, P.O. Box 30, Filabusi, Zimbabwe. Email joseph.musara@gsu.ac.zw, Orcid 0000-0002-2226-3616

${ }^{4}$ Dean of the faculty of Agricultural and Environmental Sciences at the Women's University in Africa, P.O. Box GD 32, Greendale, Harare, Zimbabwe. Email gnyamus@gmail.com

5 Lecturer Environmental Management at the Women's University in Africa, Faculty of Agricultural and Environmental Sciences, P.O. Box GD 32, Greendale, Harare, Zimbabwe. Email tawandakaseke1@ gmail.com
} 
land towards the macadamia nuts trees. Decentralization of macadamia nuts markets and localized value addition needs to be done to realign domestic and export market prices.

Key words: Climate change management, macadamia nuts, small holder farmers, value chain

\section{INTRODUCTION}

In Zimbabwe, increased temperatures and changes in precipitation (mainly an increase in the frequency of shortened rain seasons and long drought periods) due to climate change, will impact the landscape and the livelihoods of the rural population (Musakwa,Mpofu and Nyathi, 2020:4610). As the temperatures increase, vector-borne diseases and pests, that influence cropping cycles, trees, humans, and livestock are expected to shift towards extreme high levels (Baul, Ullah, Tiwari, and McDonald, 2013: 618). The farmers need to be cushioned from the negative impacts of climate change to achieve food security. Geospatial models have shown an elevational and regional shift for the cash-crops banana and coffee (Ranjitkar, Sujakhu, Lu, Wang, Wang, He, Zomer, 2016:267) and macadamia (Barrueto, Merz, Hodel, and Eckert, 2017:866). Some researchers compared results for staple crops; where rice and wheat are predicted to thrive, but maize cultivation will likely decline by 2050 due to warming (Malla 2008:65; Poudel and Kotani 2013:346).

About 70\% of Zimbabwe's population lives in rural areas (Tirivangasi, 2019:596), and practices agriculture alongside the extraction of forest products. More than $75 \%$ of the macadamia production is rain-fed and is impacted by unpredictable weather patterns (Parwada, Mudumbu, Tibugari, Badze, and Mhungu, 2020:7). The small-scale macadamia nuts farms are 0.3 to 3 hectares on average sizes. The macadamia production is highly sensitive to climate change and its impact can already be felt through increased frequency and intensity of extreme weather events. The farmers in these fragile landscapes show a tendency to adapt to climate change by adopting different survival strategies, like farmer-managed irrigation systems, agrobiodiversity, agroforestry, and community forest management (Parwada, Gadzirayi, Muriritirwa, and Mwenye, 2010:353). Many can also migrate to urban areas in search of greener pastures.

Macadamia tree is an evergreen fruit crop. They are basically, 3 species with commercial importance that are Macadamia integrifolia, M. ternifolia and M. beaumont (Huett, 2004: 610). The tree originates from Australia, but is now grown in many countries, including South Africa, Kenya, China, Guatemala, Malawi, Zimbabwe and Brazil (Mitchell \& Maddox, 2010:105). Once established, the trees take about 5 years before the first fruit set and 10 years to reach full maturity. Macadamia requires warm temperatures and high (>850 mm) annual rainfall to yield a good crop, thus the biggest threats to production are droughts, extremely high temperatures and heavy frost. The production of macadamia is therefore directly affected by the climatic 
conditions of the growing area. Integrating the macadamia and other annual crops can improve the livelihoods of smallholders, because the tree can withstand drought conditions better than the annual crops due to its deep rooting system. The tree can provide a variety of ecosystem services such as soil and moisture conservation under its crown. In many African societies, some trees form part of the cultural sites, and thus help in supporting, regulating, and promoting cultural services that contribute to human well-being and reduce social vulnerability (Locatelli, Evans, Wardell, Andrade, \& Vignola, 2011:440). Basing on fact that the macadamia has the potential to yield better than most of the annual crops under relatively unfavorable climatic conditions, the tree can be a strategic cash-crop in the wake of climate change. However, this requires a wellorganized value addition chain if farmers are to benefit more from the crop. Most studies about the impact of climate change on agriculture focus on irrigation-demanding crops; less is known about agroforestry, which can be the solution to addressing the future uncertainty of food security of smallholder farmers (Parwada et al., 2010:352; Locatelli et al., 2011: 435).

The global production of the macadamia has continuously increased in recent years. This trend is expected to continue in the future and the global nut-in-shell volume was anticipated to reach 232,428 t in 2019, a 4\% increase from 2018 (Nagao, Hirae, \& Stephenson, 1992:455). However, this was $1 \%$ less than the forecast, putting the market in tight supply and providing minimal inventory leading into 2020 (Quiroz, Kuepper, Wachira, \& Emmott, 2020: 36). The projections until 2025 anticipate a further significant growth to 700,000 t nut-in-shell. Meanwhile, the kernel forecasts are less positive, with an anticipated 60,630 $\mathrm{t}$ in 2019, a year-on-year increase of $2 \%$. (Hardner, Peace, Lowe, Neal, Pisanu, Powell, Williams, 2009:40). In Australia, the producers were affected by abnormally long, hot and dry summer, resulting in a smaller nut size (Carr, 2013:80).

At the global scale, Zimbabwe is ranked fourth with approximately $4.878 \mathrm{t}$ nut-in-shell macadamia, however, the least on kernel production with <1 t (ITC Trademap, 2019). This clearly indicates that bulk of the Zimbabwe produced macadamia is sold raw (nut-in-shell). It is therefore imperative to create value chains (VCs) and improving agro-processing of the macadamia. An industrialization roadmap was proposed focusing on developing regional VCs where Zimbabwe and the SADC region as a whole can capitalize on opportunities and future strengths and develop VCs that will participate in global VCs. Regardless of whether the local and regional VCs are a means to an end that displace macadamia markets or used as a mechanism to compete more efficiently in global VCs, the reality remains that the Zimbabwean farmers still need greater levels of both intra-regional trade and access to foreign markets (SADC, 2013). In support for such efforts, governments must have the political will and necessary infrastructure; the broader investment climate must be conducive to developing crossborder and regional linkages; and industry leaders must be willing and active participants in driving the creation of regional VCs (FAO. 2013). At the global scale, Zimbabwe is ranked 
fourth with approximately $4.878 \mathrm{t}$ nut-in-shell macadamia, however, the least on kernel production with $<1 \mathrm{t}$ (ITC Trademap, 2019).

This clearly indicates that bulk of the Zimbabwe produced macadamia is sold raw (nut-in-shell). It is therefore imperative to create value chains (VCs) and improving agro-processing of the macadamia. An industrialization roadmap was proposed focusing on developing regional VCs where Zimbabwe and the SADC region as a whole can capitalize on opportunities and future strengths and develop VCs that will participate in global VCs. Regardless of whether the local and regional VCs are a means to an end that displace macadamia markets or used as a mechanism to compete more efficiently in global VCs, the reality remains that the Zimbabwean farmers still need greater levels of both intra-regional trade and access to foreign markets (SADC, 2013). In support for such efforts, governments must have the political will and necessary infrastructure; the broader investment climate must be conducive to developing crossborder and regional linkages; and industry leaders must be willing and active participants in driving the creation of regional VCs (FAO. 2013).

Regardless of the limited value additions on the macadamia, experts still see growth opportunities in international markets for the nuts like in Europe. The Zimbabwean farmers can utilize these opportunities if the quality standards of buyers can be fulfilled. The Macadamia nuts are often processed by roasting and salting them after arrival in consumer markets. While no detailed figures on macadamia volumes in prepared and preserved nuts segments are available, production of these types of products is showing a continuous increase in the EU (Quiroz, Kuepper, Wachira, Emmott, 2019). International trade experts see less potential for exports of value-added products like confectionary or savoury snacks from the developing nations.

In Zimbabwe, most macadamia farmers are smallholders with limited livelihood options other than subsistence agriculture and small-scale farming. Stresses in agriculture, notably climate changes expose the farmers due to a reduction in productivity and changes in cropping patterns. However, there is limited understanding on the impact of climate change on the cultivation of the macadamia nut as a climate change strategic crop in the smallholder farmers of Zimbabwe. The aim of this study was to evaluate the potential of value chains in macadamia nuts as a climate change resilience strategy. The specific objectives were to; (1) understand the impact of climate change on macadamia production in the Chipinge district, Manicaland, Zimbabwe; (2) examine the marketing and value addition chains of the macadamia nuts in the Chipinge area; and (3) discuss implications for future areas for macadamia nuts production and marketing with the policymakers. 
S. Afr. J. Agric. Ext.

Vol. 49 No. 3, 2021: 62-75

http://dx.doi.org/10.17159/2413-3221/2021/v49n3a12852
Bandason, Parwada, Musara, Nyamushamba \& Kasek

(License: CC BY 4.0)

\section{METHODOLOGY}

\subsection{Description of study area and data collection}

The study was conducted in Chipinge district which is located in Manicaland province, SouthEastern Zimbabwe, close to the border with Mozambique. The town lies approximately 170 kilometres, by road South of Mutare city and about 239 kilometres, East of Masvingo city. The study area lies at coordinates $20.1938^{\circ} \mathrm{S}, 32.6206^{\circ} \mathrm{E}$ and at an average elevation of $1132 \mathrm{~m}$. Average annual rainfall in the district is about $1105 \mathrm{~mm}$ with an average temperature of $12^{\circ} \mathrm{C}$. The climate in the study area is well suited for agriculture as a strategic livelihood option. However, some parts of the district receive rainfall as low as $350 \mathrm{~mm}$ with temperatures averaging $29^{\circ} \mathrm{C}$. Farmers grow macadamia nuts, tea, coffee and rear dairy cattle for food and income. The surrounding mountain slopes are covered with pine and acacia plantations. These varied climatic conditions imply that decisions about climate change mitigation strategies need to be context specific. Figure 1 shows the location of the study area.

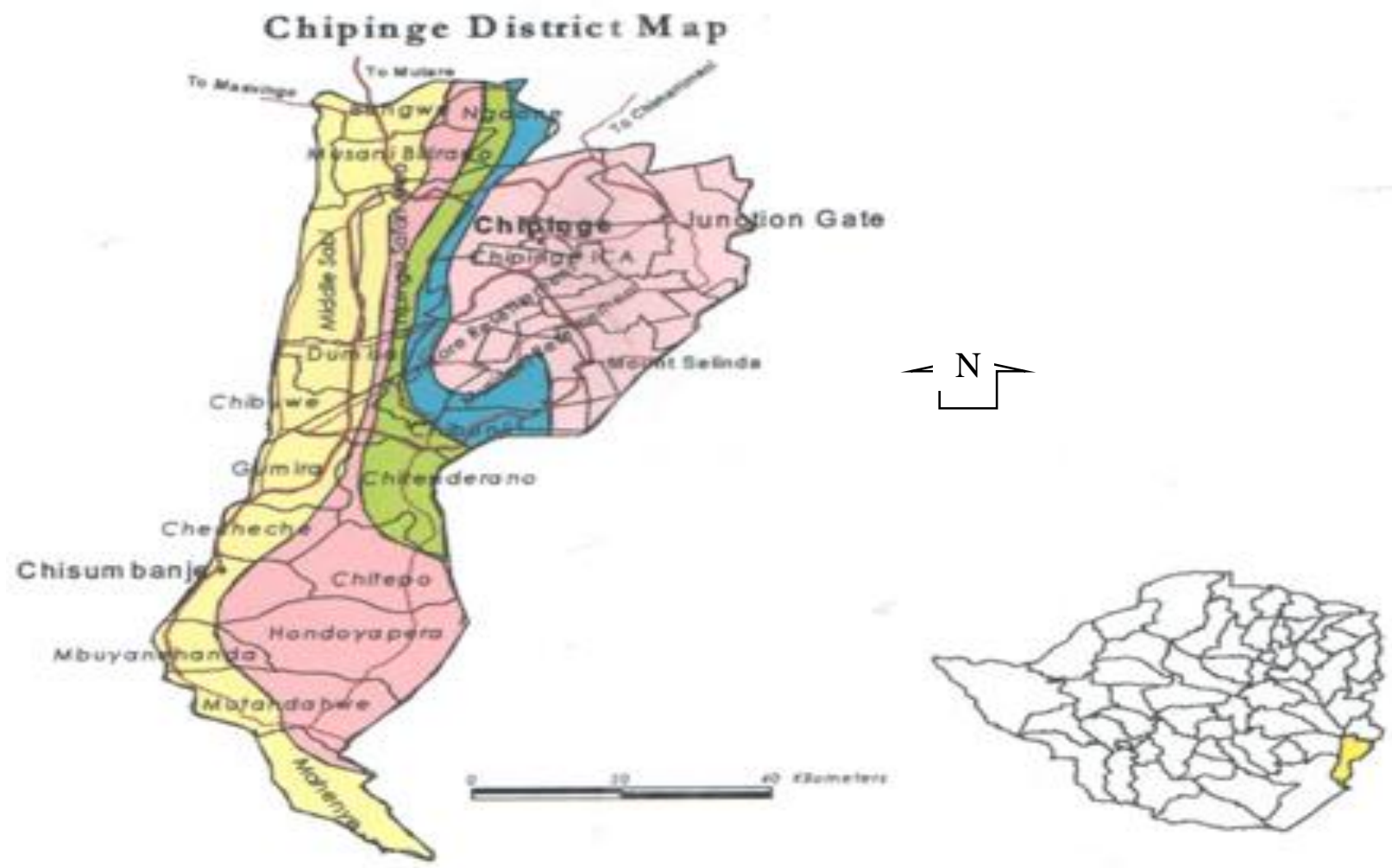

\section{FIGURE 1: Geographical location of Chipinge district in Zimbabwe}

Given the nature of the study, a mixed methods approach was more appropriate since it covered both qualitative and quantitative dimensions. The study mainly used secondary data collected from Agritex within a survey design. Key informant interviews were also done with other 
strategic value chain stakeholders including association members, buyers and Agritex officials. Guided by Seale (2002:103), multi stage sampling was adopted for the study. Figure 2 shows the stages that we used in sampling and data collection.

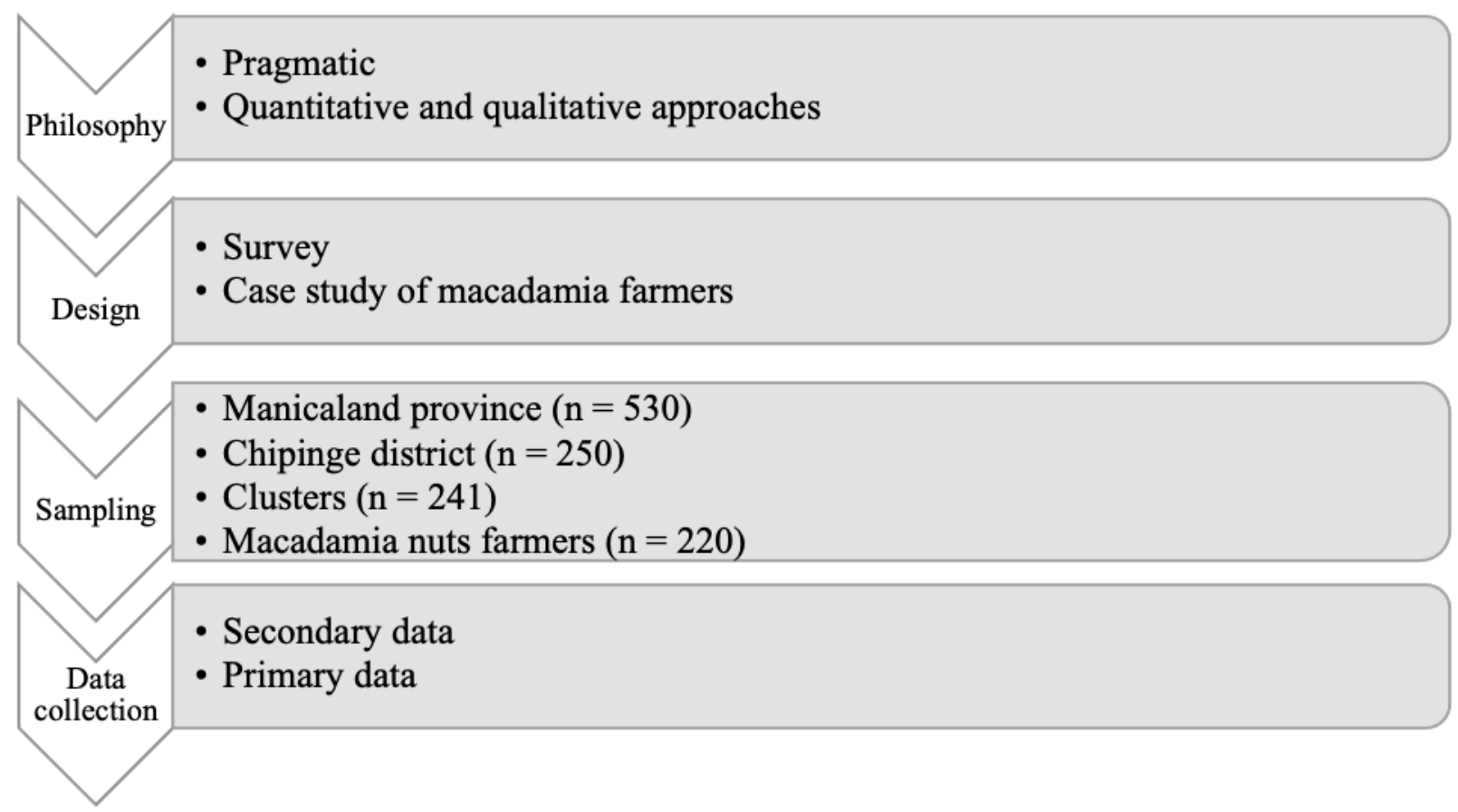

\section{FIGURE 2: Summary of sampling and data collection methods}

Manicaland province and Chipinge district were purposively selected because the area is one of the prime zones which produce macadamia nuts in Zimbabwe. To cater for the production variations, the macadamia nuts farmers were then categorised into clusters based on the scale of production as Estates, A1 and A2 farmers. The A1 model is a resettlement land tenure system in Zimbabwe focused on smallholder production where village arrangements or small, selfcontained farms averaging 3-7 ha for cultivation with shared grazing depending on region were allocated to farmers. The A2 model is focused on commercial production at a larger scale and is characterized by individualized ownership with land holdings ranging from 100 to 1500ha (Nkomboni and Beekman 2015). Questionnaires were administered to a total of 220 were then randomly selected macadamia nuts producing farmers from the clusters. Information about the farm area under macadamia, estimated yield of macadamia per hectare, buyers and prices per $\mathrm{kg}$ of macadamia nuts and whether there is any form of value addition of the nuts before selling.

\subsection{Empirical analysis of the production and marketing data}

The study mainly adopted descriptive analyses strategies. Production and marketing data were analysed for variations and trends so as to understand how best interventions can be designed to strategically position macadamia nuts as a core component of climate change resilience. 
Modified stakeholder analysis was also done so as to categorise constraints associated with production and marketing of macadamia nuts in the study area.

\section{RESULTS AND DISCUSSION}

This section presents and discusses results of the study. The study sought to bring about an understanding of the impact of climate change on macadamia production in the Chipinge district, Manicaland, Zimbabwe. I also sought to examine the marketing and value addition chains of the macadamia nuts in the Chipinge area as well as discuss implications for future areas for macadamia nuts production and marketing with the policymakers. Understanding of the issues will help extension service providers understand the implications of climate change and how a tree crop like macadamia nuts can mitigate against the challenges.

\subsection{Farm cluster distribution and registration status}

Table 1 shows the cluster distribution of farms farms involved in mavadamia nut production in the study area.

TABLE 1: Distribution of farm clusters

\begin{tabular}{|l|l|l|}
\hline A1 & A2 & Estate \\
\hline $80.5 \%$ & 18.3 & $1.2 \%$ \\
\hline
\end{tabular}

The dominant farm cluster accounting for $80.5 \%$ is the A1 model which, however, produces the least quantities of nuts on smaller pieces of land using outdated systems. Estates are also present on the production platform and constitute $1.8 \%$ of the sampled units. Going forward, if composite benefits are to be extracted from macadamia nuts, the estates that are surrounded by small-scale producers should consider adopting the nucleus model as is the case with coffee and tea. This way, they work with the smaller farmers to help them produce better quality macadamia nuts that can then be processed locally or sold to more lucrative export markets.

Table 2 shows the the registration status of farms in that produce macadamia nuts in the study area.

TABLE 2: Registration status of farmers

\begin{tabular}{|l|l|}
\hline Registered (\%) & Unregistered (\%) \\
\hline 96 & 4 \\
\hline
\end{tabular}

Most farmers (96\%) are formally registered. This can be used as an opportunity to pull resources together and self finance for the growth of the macadamia nuts value chain. Key Informant Interviews showed that there is a farmer association which coordinates production and marketing 
for the registered farmers. Worringly, small scale farmers still remain inactive in high value markets. This points towards the need for a small sale farmers' associations which specifically addressed their unique needs and not blanket them in the same group as Estates who may have different expectations and needs from the association. Lundy (2012) also recommended a similar strategy in linking small holder farmers to markets.

\subsection{Varieties grown and selected summary statistics}

There are two main varieties grown in the area namely Beaumont and Integrifolia (Table 3). The size of the nuts produced is dependent on water and nutrient supply. It becomes important for farmers to have access to other varieties which can do better in the localities while not exerting pressure on the few resources which they have.

\section{TABLE 3: Macadamia nut varieties produced by farmers}

\begin{tabular}{|l|l|}
\hline Integrifolia (\%) & Beaumont $(\boldsymbol{\%})$ \\
\hline 52 & 48 \\
\hline
\end{tabular}

Table 4 shows the average yield per tree per year from the area of study to be relatively lower $(13.805 \mathrm{~kg})$. Small scale macadamia nut producers' trees over 5 years of age have been reported to yield over $20 \mathrm{~kg}$ of nuts per year depending on the growing region (Zuza, Maseyk, Bhagwat, Emmott, Rawes, and Araya, (2021:3).

TABLE 4: Summary statistics for selected variables

\begin{tabular}{|l|l|l|l|l|}
\hline Statistic & $\begin{array}{l}\text { Area under } \\
\text { macadamia nuts (ha) }\end{array}$ & $\begin{array}{l}\text { Number of } \\
\text { trees }\end{array}$ & $\begin{array}{l}\text { Yield per } \\
\text { tree (kg) }\end{array}$ & $\begin{array}{l}\text { Total annual } \\
\text { yield (tonnes) }\end{array}$ \\
\hline Mean & 15.224 & 5623.705 & 13.805 & 259.184 \\
\hline Std. Deviation & 67.256 & 21563.319 & 10.048 & 2005.486 \\
\hline Minimum & 0.02 & 5.00 & 2.00 & 0.01 \\
\hline Maximum & 875.00 & 171000.00 & 108.00 & 27928.80 \\
\hline
\end{tabular}

\subsection{Buyers and relative market prices}

The major buyers in the macadamia nuts market chain are Parrogate Pvt Ltd, Cropate, Mac Nut Company Afri-China and Sime. There are sign of collusion by the buyers who offer low prices to the farmers. There is, however, scope for expanding the market size in the area and create opportunities for the farmers to competitively sell their produce. Alternative markets for small nuts also exist in South Africa. However, the buyers stagger payments and only pay fully after cracking and processing the nuts. This is a disadvantage to the farmers who expect instant payments for their produce. Table 5 shows a comparison of export and domestic prices. Export market prices are almost double the prevailing domestic prices. 
TABLE 5: Comparative domestic and export markets prices

\begin{tabular}{|l|l|}
\hline Domestic market price (US\$/kg) & Export market price (USD/kg) \\
\hline 2.65 & 4.85 \\
\hline
\end{tabular}

The policy and institutional frameworks in Zimbabwe can therefore be reconfigured to push the domestic prices up. The starting point is for farmers and farmer associations to re-think their marketing strategies and establish a bargaining power base in the domestic markets. If farmers get favourable prices in domestic markets, then this should have a cascading effect on possible local value addition prospects which can be designed to be done in the localities of production. A similar pattern was reported by Maina et al. (2014:89). This way, the transaction costs will be reduced while increasing the marketing margins accruing to the farmers. If this happens, then the climate change adaptation capabilities of the macadamia nuts will have a cascading effect on the welfare of the farmers.

\subsection{Major challenges experienced by macadamia nuts stakeholders \\ 3.4.1 Production challenges}

Small scale macadamia nuts farmers reported the challenge of high prices of inputs, their late acquisition and unreliable quality inputs in their effort to migrate towards market oriented macadamia nuts production. Most previous studies (for example Maina et al., 2012; Rukuni et al., 2006) also acknowledge that, requisite production resources such as fertilizers and pesticides are expensive while quality seed of different varieties are relatively available but have not been adequately multiplied (Ricker-Gilbert, Jayne, \& Chirwa, 2011:30). Agricultural finance resources also play an essential role in the success of farming activities due to its catalytic effects on access to production factors. The deficiency of reliable rural finance options has adversely affected macadamia nuts production (and marketing) potential among small scale producers of Zimbabwe, just like most crop enterprises. There has been an attempt to finance production by buyers and some banks, but it has been noted that challenges exist in the operationalization of the finance models. Unsustainable financing models in these farming areas imply that farmers mainly rely on personal savings, loans from friends and relatives and cash from non-farm sources to finance agricultural activities.

We note that sustainable contracts for the macadamia nuts can also go a long way in ensuring availability of inputs to farmers. A number of studies show the potential of farmer cooperatives in facilitating access not only to input markets but also to output markets (Makindara et al., 2013:4). Faced with these challenges and low yields, farmers in the arid areas reserve most of the land and resources to food production for household consumption given that there are limited opportunities for major cereal crops such as maize. This further exposes them to welfare insecurity caused by climate change induced challenges. Supported macadamia nuts production can offer a gateway out of this dilemma. 


\subsubsection{Post-production challenges}

Farmers and other stakeholders indicated that they are facing challenges in export market platforms due to lack of adequate capacity to meet their standard requirements. The transaction costs associated with these markets are also high and dampen the prospects of farmers to participate on these platforms. These two intertwined factors are compounded by a number of other factors like the complexity of negotiations and access to the export markets. Musara et al. (2019:188) also identify the impact of marketing policy on the marketing channel mix in resource constrained small scale farming systems which often force farmers to participate in markets that they may not have preferred. This has greatly distorted the structure, conduct and performance in macadamia value chains. If lessons are drawn from these experiences, this can help to strengthen the currently existing value chain nodes and tap further into other latent marketing alternatives. This will establish a concrete foundation for macadamia nuts to contribute towards household welfare and growth in the national economy of Zimbabwe. As suggested by Lundy (2012), to achieve this, more integrated and direct private sector interventions which grease market linkages across all pillars of this value chain need to be adopted.

Evidence further shows that, in Zimbabwe, there is a current gap in research on market linkages that exist in macadamia nuts value chains, the associated challenges, their responsiveness to change and their appropriateness in various contexts. Results from our study also point towards a similar trend where the major challenge for farmers and buyers alike is that the Asian markets who dominate in the transactions prefer larger nuts which farmers cannot easily produce. However, since most farmers produce the smaller nuts, they end up being stuck with the nuts. Additionally, in most cases there is evidence that marketing logistics tend to become more complex with traders and middlemen controlling the export market, thereby creating a breeding ground for exploitation of farmers for prices through use of manipulated standard requirements. A point in case is the payment lags which, at times, go beyond the acceptable normal practice in most companies. This affects the planning on the part of farmers and further pulls them back to domestic markets. Alternatively, this puts pressure on the storage costs, a burden which the small-scale macadamia nuts farmer cannot absorb. It therefore becomes inevitable to consider investing in local value addition structures for such nuts to process into products such as oil and confectionaries.

\subsubsection{Crosscutting and extension challenges}

Results show that there is a missing link of private-public partnerships towards supporting and tapping value from emerging and more strategic value chains especially in areas where macadamia nuts can do well like Chipinge district, Zimbabwe. For example, maize systems are oversubscribed but due to climate change drivers, the crop does not perform well in some environments. This policy imbalance has also greatly affected the potential of macadamia nuts 
value chain. Compounding this is the reality that, the extension service delivery for the nuts is mainly inefficient with limited effective interaction between extension agents, farmers and other stakeholders. There is need to find alternative solutions to enhance extension modes with adequate response mechanisms in the wake of evolving value chain indicators such as prices and consumer preferences (Mabiso, Cunguara, \& Benfica, 2014:655). Information related to production practices, marketing and associated changes in innovations is an indispensable ingredient in effective decision making on enterprise choice by small scale farmers (Musara et al., 2019:180). In small scale farming communities, the fundamental issues of storage, processing and marketing of macadamia nuts is mainly affected by poor and dysfunctional networks at all levels and thus the value chain has greatly remained rudimentary, uninformed and subsistence oriented. The potential of macadamia nuts as a climate change resilience alternative therefore needs to be tapped if the diversity of cropping systems is to be positively aligned in areas such as Chipinge district of Zimbabwe.

\section{CONCLUSIONS AND IMPLICATIONS FOR POLICY}

This paper examines the potential for developing a climate change responsive macadamia nut value chain within semi-arid Zimbabwe by strategically placing smallholder producers in the vicinity of other stakeholders. The role of local markets and producers in the international trade in macadamia nuts was also explored using a modified stakeholder analysis framework. The study concludes that the coordination of production and marketing activities is weak. Rudimentary production systems are still being used especially by the A1 and A2 farmers. Innovations to enhance productivity, which in most cases is also associated with quality, have not been adopted at a scale which can help farmers to go beyond the multiple constraints which they face. Ultimately, the small-scale farmers do not adequately participate in the export markets which can offer them higher returns to their investments. Given the findings, it is therefore necessary for policymakers to learn from the experiences in Chipinge district and design a more regional value chain for the macadamia nut industry in Zimbabwe. The fundamental ingredients should hinge on enhancing productivity while also creating an accommodative marketing policy

which does not crowd out the small-scale farmers. This strategy should also cascade to the value chain's ability to self-evolve in response to the dynamic climate change realities while improving the welfare of the small-scale macadamia nuts producers. Furthermore, the level of access to information about climate change and best coping mechanisms need to be heightened to raise awareness that will enhance adaptations to climate change. An informed and well-equipped extension service can better articulate the adoption of macadamia nut production as a part of the climate change resilience strategies. 
S. Afr. J. Agric. Ext.

Vol. 49 No. 3, 2021: 62-75

http://dx.doi.org/10.17159/2413-3221/2021/v49n3a12852
Bandason, Parwada, Musara, Nyamushamba \& Kasek

(License: CC BY 4.0)

\section{REFERENCES}

BARRUETO, A.K., MERZ, J., HODEL, E. \& ECKERT, S., 2018. The suitability of Macadamia and Juglans for cultivation in Nepal: An assessment based on spatial probability modelling using climate scenarios and in situ data. Regional environmental change, 18(3): 859-871.

BAUL, T.K., ULLAH, K., TIWARI, K.R. \& MCDONALD, M.A., 2013. Peoples knowledge of climate change in the Middle Hills of Nepal. Small-scale forestry, 12(4): 611-629.

CARR, M., 2013. The water relations and irrigation requirements of macadamia (Macadamia spp.): a review. Experimental Agriculture, 49(1): 74-90.

FAO., 2013. Enabling environments for agribusiness and agro-industries development Regional and country perspectives. Rome, Italy.

HARDNER, C.M., PEACE, C., LOWE, A.J., NEAL, J., PISANU, P., POWELL, M. \& WILLIAMS, K., 2009. Genetic Resources and Domestication of Macadamia. Horticultural reviews, 35(1): 34-48.

HUETT, D., 2004. Macadamia physiology review: a canopy light response study and literature review. Australian Journal of Agricultural Research, 55(6): 609-624.

ITC TRADE MAP., 2019. List of importing markets for a product exported by Kenya: Product: 080262 Fresh or dried macadamia nuts, shelled [viewed 18 November 2020]. Available from https://www.trademap.org.

LOCATElli, B., EVANS, V., WARDELl, A., ANDRADE, A. \& VIGNOLA, R., 2011. Forests and climate change in Latin America: linking adaptation and mitigation. Forests, 2(1): 431-450.

LUNDY, M., 2012. LINK methodology: A participatory guide to business models that link smallholders to markets. [viewed 18 October 2020]. Available from: https://www.valuechains.org/dyn/bds/docs/838/LINKMethodology.pdf.

MALLA, G., 2008. Climate change and its impact on Nepalese agriculture. Journal of agriculture and environment, 9: 62-71.

MABISO, A., CUNGUARA, B. \& BENFICA, R., 2014. Food (In)security and its drivers: Insights from trends and opportunities in rural Mozambique. Food Security, 6(5): 649670.

MACHINGAMBI, M. \& MANZUNGU, E., 2003. An evaluation of rural communities' water use patterns and preparedness to manage domestic water sources in Zimbabwe. Physics and Chemistry of the Earth, Parts A/B/C, 28(20-27): 1039-1046.

MAINA, I., MIRUKA, M., RONO, B., NJERU, P.N., AMBOGA, S., GITARI, J., MAHASI, M. \& MURITHI, F., 2012. Adaptive strategies and local innovations of smallholder farmers in selected agri-food systems of central Kenya. African Crop Science Journal, 20(1): 7784. 
MAKINDARA, R., HELLA, J.P., ERBAUGH, J.M. \& LARSON, D.W., 2013. Consumer preferences and market potential for sorghum based clear beer in Tanzania. Journal of Brewing and Distilling, 4(1): 1-10.

MITCHELL, A. \& MADDOX, C., 2010. Bark beetles (Coleoptera: Curculionidae: Scolytinae) of importance to the Australian macadamia industry: an integrative taxonomic approach to species diagnostics. Australian Journal of Entomology, 49(2): 104-113.

MUSAKWA, W., MPOFU, E. \& NYATHI, N.A., 2020. Local Community Perceptions on Landscape Change, Ecosystem Services, Climate Change, and Livelihoods in Gonarezhou National Park, Zimbabwe. Sustainability, 12(11): 4610.

MUSARA, J.P., MUSEMWA, L., MUTENJE, M., MUSHUNJE, A. \& PFUKWA, C. 2019., Determinants of sorghum adoption and land allocation intensity in the smallholder sector of semi-arid Zimbabwe. Spanish Journal of Agricultural Research, 17(1): e0105. https://doi.org/10.5424/sjar/2019171-13115.

MUSARA, J.P., MUSEMWA, L., MUTENJE, M., MUSHUNJE, A. \& PFUKWA, C. 2018., Market participation and marketing channel preferences by small scale sorghum farmers in semi-arid Zimbabwe. Agrekon, 57(1): https://doi.org/10.1080/03031853.2018.1454334.

NAGAO, M. A., HIRAE, H. H. \& STEPHENSON, R., 1992. Macadamia: cultivation and physiology. Critical Reviews in Plant Sciences, 10(5): 441-470.

NKOMBONI, P. \& BEEKMAN, S., 2015. Beef value chains in A2 resettled farms in Zimbabwe: A review. Livestock Research for Rural Development. Volume 27, Article \#123. Retrieved October 12, 2020, from http://www.lrrd.org/lrrd27/7/nkom27123.html.

PARWADA, C., GADZIRAYI, C., MURIRITIRWA, W. \& MWENYE, D., 2010. Adoption of agro-forestry technologies among small-holder farmers: A case of Zimbabwe. Journal of Development and Agricultural Economics, 2:351-358.

PARWADA, C., MUDUMBU, R., TIBUGARI, H., BADZE, D. \& MHUNGU S., 2020. Effect of soil fertility amendment, planting planting density and growing season of Chenopodiu quinoa willd (Quinoa) in Zimbabwe. Cogent Food \& Agriculture, 6 (1): 1-16. 1792668, DOI: 10.1080/23311932.2020.1792668.

POUDEL, S. \& KOTANI, K., 2013. Climatic impacts on crop yield and its variability in Nepal: do they vary across seasons and altitudes? Climatic change, 116(2): 327-355.

QUIROZ, D., KUEPPER, B., WACHIRA, J. \& EMMOTT, A., 2019. Value Chain Analysis of Macadamia Nuts in Kenya, research commissioned by CBI, Amsterdam, the Netherlands: Profundo. (pp1-87).

QUIROZ, D., KUEPPER, B., WACHIRA, J. \& EMMOTT, A., 2020. Value Chain Analysis of Macadamia Nuts in Kenya. 
S. Afr. J. Agric. Ext.

Vol. 49 No. 3, 2021: 62-75

http://dx.doi.org/10.17159/2413-3221/2021/v49n3a12852
Bandason, Parwada, Musara, Nyamushamba \& Kasek

(License: CC BY 4.0)

RANJITKAR, S., SUJAKHU, N.M., LU, Y., WANG, Q., WANG, M., HE, J. \& ZOMER, R.J., 2016. Climate modelling for agroforestry species selection in Yunnan Province, China. Environmental Modelling \& Software, 75: 263-272.

RICKER-GILBERT, J., JAYNE, T.S. \& CHIRWA, E., 2011. Subsidies and crowding out: A double-hurdle model of fertilizer demand in Malawi. American Journal of Agricultural Economics, 93(1): 26-42.

RUKUNI, M., TAWONEZVI, P., EICHER, C., MUNYUKI-HUNGWE, M. \& MATONDI, P., 2006. Zimbabwe's agricultural revolution revisited. University of Zimbabwe Publications, Harare.

SOUTHERN AFRICAN DEVELOPMENT COMMUNITY SECRETARIAT, INDUSTRIALISATION STRATEGY AND ROADMAP., 2015-2063. GABORONE: SADC Secretariat, April 2015.

SEALE, C., 2002. Quality issues in qualitative inquiry. Qualitative Social Issues, 1(1): 97-110.

TIRIVANGASI, H.M., 2019. Challenges faced by rural people in mitigating the effects of climate change in the Mazungunye communal lands, Zimbabwe, Jamba: Journal of Disaster Risk Studies 11(1): a596. https://doi.org/10.4102/jamba.v11i.596.

ZUZA, E.J., MASEYK, K., BHAGWAT, S., EMMOT, A., RAWES, W. \& ARAYA, Y.N., 2021. Focusing on what, where, how much is produced and major constraints. Agriculture,2021 11, 52. https://doi.org/10.3390/agriculture11020152 pp1-19. 